\title{
Muslim Estate Administration: The Locus of Malaysian Syariah Court in Malaysia
}

\author{
MUHAMAD HELMI MD SAID, MUHAMMAD AMRULLAH BIN DRS NASRUL, \\ NORA ABDUL HAK \& WAN NORAINI MOHD SALIM ${ }^{1}$
}

\begin{abstract}
The concept of dual justice system practiced in Malaysia governs the area of inheritance where there is a notable difference between Muslim and non-Muslim estate administration. While the non-Muslims deal solely with civil court, the Muslims are governed under both civil and Syariah Court. For Muslims, reference to Syariah Court is required for the purpose of obtaining the fara'id certificate, prior to the application to other administrative bodies. Having to deal with multiple bodies tends to lead to a confusion among the Muslims as to which institution should they approach, signifying the extra commitment that they will have to make. The complexity of the process encountered by the beneficiary results in discouragement to proceed the administration which eventually led to delay in estate administration and distribution. The lack of understanding regarding the function of the Syariah Court holds as a key factor to this ongoing issue. This paper adopts the librarybased research which focuses on the analysis of written sources including but not being limited to journal articles, statutes, case laws and text books. In its findings, this paper states that there is a need for the government to re-look into the structure of the administrative bodies by making proper amendments in order to simplify the current process of the Muslim estate administration.
\end{abstract}

Keywords: Family, Administrative bodies, estate administration, inheritance certificate and jurisdiction.

The Syariah Court plays a significant role in matters pertaining to Muslim inheritance as one of the administrative bodies. Although the extent of jurisdiction and power possessed by the Syariah Court may not be as wide as the civil court, the role of the Syariah Court in this context is nevertheless substantial as it literally determines the recipients and their respective portion by way of faraid formula. This fact justifies the reason behind the Syariah Court being the first administrative body which the beneficiaries need to approach, not only for the issuance of Inheritance Certificate but for the purpose of resolving other related matters which are under the jurisdiction of the Syariah Court (Nasrul \& Mohd Salim 2018). Upon the settlement of these matters, only then the beneficiaries may proceed in applying for the letters of representation from other administrative bodies namely the

${ }^{1}$ Muhamad Helmi Md Said, Ph. D*. (corresponding author), Senior Lecturer at Faculty of Law, Universiti Kebangsaan Malaysia, 43600 BANGI, Selangor, Malaysia. Email: mhelmisaid@ukm.edu.my; Muhammad Amrullah bin Drs Nasrul, Ph. D., Asst. Prof. at Ahmad Ibrahim, Kulliyyah of Laws, International Islamic University Malaysia, 53100 Jalan Gombak, KUALA LUMPUR, Malaysia. Email: amrullah@iium.edu.my; Nora Abdul Hak Ahmad, Ph. D., Professor at Ahmad Ibrahim Kulliyyah of Laws, International Islamic University Malaysia, 53100 Jalan Gombak, KUALA LUMPUR, Malaysia. Email: ahnora@iium.edu.my; Wan Noraini Mohd Salim, Ph. D., Asst. Prof. at Ahmad Ibrahim Kulliyyah of Laws, International Islamic University Malaysia, 53100 Jalan Gombak, KUALA LUMPUR, Malaysia. Email: w.noraini@iium.edu.my

$$
\text { https://doi.org/10.24035/ijit.19.2021.197 }
$$


civil High Court or Amanah Raya Berhad (ARB) or in certain cases, the Estate Distribution Unit (Samori, et.al. 2016). Ironically, this situation adds up to the burden on the Muslims as they have to deal with two administrative bodies which practically is considered cumbersome compared to the non-Muslims. Since the civil law also governs part of the inheritance matter, reference therefore involve both syariah courts and civil courts (Omar and Muda, 2017).

\section{Issuance of Faraid Distribution Order (Inheritance Certificate) by the Syariah Court}

The jurisdiction of the Syariah Court in inheritance matters is stated under Section 46(2) and Section 50 of the Administration of Islamic Law (Federal Territories) Act 1993 (Baharuddin \& Mohamed Said 2017). The earlier provision mentioned the authority of the Syariah High Court to hear and determine the distribution of testate and intestate cases while the later specifies about the requirement of the Inheritance Certificate in determining the entitled heirs and their fixed portion under the rules of faraid (Zulkifli, Batiha \& Qasim, 2018).

Before an application for letters of representation can be made either from the civil High Court and ARB, Inheritance Certificate must first be obtained from the Syariah Court (Ab Rahman, et. al. 2018). With the exception to the Estate Distribution Unit, the requirement is dispensed as the Land Administrator possesses the expertise to do calculation on the portions of the beneficiaries under faraid, hence dispersing the need to apply for Inheritance Certificate from the Syariah Court (Nasrul \& Mohd Salim, 2017). Reference to the Syariah Court by the land administrator shall only be made in cases which involve complex calculation, as stipulated under Section 19 of the Small Estate (Distribution) Act 1959 (Shafie, Wan Yusoff \& El-Edrus, 2016). An example of complex calculation involves situations which require the land administrator to determine a group of beneficiaries, ranging from multiple generations. This situation normally happens in a series of death involving beneficiaries who passed away before obtaining their portions from the deceased's asset. In addition, the Estate Distribution Unit does not issue the Inheritance Certificate, but state the portions for each of the beneficiaries in accordance to faraid in its Distribution Order or Letter of Administration, both represented by Form E and Form F respectively (Ahmad Sanusi et al. 2017)

In its technical term, Inheritance Certificate refers to an order issued by the Syariah Court which contains a list of the beneficiaries who are entitled to the estate of the deceased together with the exact portion entitlement of such asset calculated according to the rule of faraid, as endorsed by the judge. The objective of such issuance is to ensure that no entitled beneficiaries were excluded and each of them will get the exact share accordingly. In fact, the Inheritance Certificate is the most reliable documentation in proving the entitled beneficiaries, compared to other documentation. This was acknowledged by the civil court in the case of Mohd Salim Said \& Ors v. Tang Pheng Kee \& Anor. According to Mohd Zawawi Salleh CJ:

"The certificates (Inheritance Certificate) were the best evidence in proving that the appellants were, in fact, the rightful beneficiaries of the deceased. The JC should have accepted an order made by a court of competent jurisdiction after due inquiry as to who were the beneficiaries of the deceased's estate."

The civil courts recognize the exclusive power of the Syariah Court as the sole competent authority to issue the Inheritance Certificate. In addition, the names stated in the said certificate are the rightful beneficiaries which have been affirmed by the syariah court judge.

There is a misperception among the public regarding the position of the Inheritance Certificate where it is regarded similar to the letters of representation and the Distribution Order issued by other administrative bodies (Bouteraa 2019). However, the nature of these three documents is in fact different. The Grant of Probate issued by the civil High Court, for instance, recognizes a person who is appointed as the executor in a will and allows him to act within his

$$
\text { https://doi.org/10.24035/ijit.19.2021.197 }
$$


capacity as a personal representative to deal with the estate of the deceased. A similar situation applies to the Letter of Administration which in essence, appoints a person as the administrator in managing and distributing the deceased's estate according to the relevant law.

On the other hand, Inheritance Certificate does not act as a Distribution Order, nor does it appoint someone as an administrator of the deceased's estate. In practice, Inheritance Certificate must first be obtained from the Syariah Court prior to the application for letters of representation. The rationale behind this is that, in the application for a Grant of Probate from the civil High Court, the judge will first refer to the Inheritance Certificate which is attached by the applicant as part of the supplemented documents. This is to identify the entitled beneficiaries as well as their respective portions. The Grant of Probate will be issued based on the information provided in the Inheritance Certificate. In other words, the power of the Syariah Court in the estate administration is only limited to issuing the Inheritance Certificate. Hence, the Inheritance Certificate does not in any way function like the Distribution Order, and thus, it cannot, for example, order the financial institution to release the deceased's money.

There are unreported cases where the Syariah Court in peninsular Malaysia has somehow exceeded its authority by issuing the Inheritance Certificate intended to function as an additional distribution order and appointing personal representative. This, however, should not be confused with the power of the Syariah Court in the state of Sabah which is authorized to appoint personal representative. The current position in peninsular Malaysia remains the same where the effect of Inheritance Certificate does not resemble the letters of representation nor the Distribution Order. The monetary value of a deceased Muslim's estate determines which Syariah Court has the jurisdiction to hear the application for the Inheritance Certificate. As for the asset's value which is below RM100, 000, the application will be heard before the Syariah Lower Court, and for any value above such amount, the case will be heard before the Syariah High Court. Even if the case was initially heard before the Syariah Lower Court, it is the Syariah High Court which will eventually certify and issue the Inheritance Certificate. The procedures will involve both Syariah Lower Court and the Syariah High Court levels. The determination of jurisdiction of the Syariah Courts based on the monetary value of the asset is similar to that of the civil courts. But in matters pertaining to the application for letters of representation, such will only be heard before the High Court as it has the exclusive jurisdiction over other subordinate courts in probate-related matters.

The jurisdiction to hear the application for the Inheritance Certificate is also based on the location where the deceased left his asset. If the deceased's asset is located in several states, the applicant is free to choose one of the states where the asset is located for the application of the Inheritance Certificate. Once granted, the Inheritance Certificate will take effect on all asset belonging to the deceased, regardless of the location.

\section{Research Limitation}

The scope of discussion in this paper only covers the jurisdiction of syariah courts in peninsular Malaysia due to the different practice of syariah courts in Sabah and Sarawak. For instance, the syariah courts in Sabah is authorized to appoint an administrator, a feature which is similar to the likes of civil High Court and small estate distribution unit. In addition, the jurisdiction of the syariah courts in Kuala Lumpur serves as the main reference of this writing, hence may involve different use of provisions as compared to other states. 


\section{Research Design}

This legal study adopts the library-based research which focuses on the analysis of written sources including but not being limited to journal articles, statutes, theses, case laws and text books. Due to various state enactments governing the matters pertaining to faraid, this paper focuses on the sole reference to the syariah law statute in Federal Territory.

\section{Analysis and Discussion}

The role of the Syariah Court in inheritance matters is undoubtedly essential as it is the sole body having the authority to determine in the matters of faraid and its related matters. Its relevancy as the administrative body however, is justifiable by looking thoroughly at the relationship between the Syariah Court and other administrative bodies. This could further explain the reason behind the requirement on the Muslim to deal with two bodies in estate cases. This part of chapter will analyze on how the Syariah Court complements its role with each administrative bodies namely the civil High Court, estate distribution unit and ARB in the administration of estate in Peninsular Malaysia.

\section{Relationship between the Syariah Court and the Civil High Court}

The relationship between the Syariah Court and the civil High Court represents the clear notion of duality of law being practiced in Malaysia. In addition, inheritance is among the subject which involve both type of jurisdictions, especially when dealing with cases involving Muslims. Although the civil court seems to have wider influence over inheritance matters, the importance of the Syariah Court cannot be denied as the Federal Constitution also mentioned its jurisdiction under the Ninth Schedule, List II (Kamarudin \& Nor Muhamad 2018).

Jurisdiction of the civil High Court in Muslim inheritance matters covers two types of situation. The first one involves cases where the deceased's asset is under the category of non-small asset. This comprises of movable asset above RM600,000 as well as solely immovable or combination between immovable and movable asset above two million ringgit. Incidentally, testate estate cases involving the deceased who died leaving a will also falls under the jurisdiction of the civil high court, even if the amount is below two million (Nasrul \& Mohd Salim 2017; Nasrul et. al. 2019).

As for the letters of representation being issued by the administrative bodies, the civil High Court is statutorily authorized to issue the Grant of Probate and the Letter of Administration (Haji Mohammada \& Suratman 2017). The former is issued in testate estate cases while the letter is in intestate estate cases. In either case, the applicant is required to first obtain the faraid inheritance certificate before applying for the letters of representation. This is because, the court registrar needs to ensure that the list of entitled beneficiaries have been determined as the function of the letters or representation is to appoint the person as executor or administrator to manage the deceased's estate. Hence, determining the recipients of the deceased's asset needs to be settled at the Syariah Court level. This rule also applies in testate estate cases as the distribution of asset under Islamic will is capped to one-third of the total asset. In this context, the syariah court judge possesses the authority in determining several matters such as ensuring that the bequeath is in line with the Islamic principle as well as determining the validity of such will (Ahmad et. al. 2017). The rule set by the civil High Court for the applicant to obtain the inheritance certificate clearly displays the importance of the Syariah Court in this matter as the document stands as one of the fundamental requirements in applying for the letter of representation. 


\section{Suggestion}

The analysis from this study shows that the requirement to deal with multiple bodies complicates the Muslim as they have to make additional effort in terms of physical, time and monetary commitment, unlike the non-Muslims which deals with a single body. In addressing the current issues, this paper is proposing the following steps, subject to cases which strictly involve faraid application. This means that, any cases which is contentious in matters such as involving the application for jointly acquired properties or determining the legitimacy of an heir or proving the validity of the Muslim will shall be excluded from such proposals.

To avoid the complication of having to deal with multiple bodies, the syariah judiciary officer should be placed at the civil High Court and ARB to entertain application for inheritance certificate. This retains the exclusive authority of the Syariah Court in matters of Muslim inheritance. The idea behind this proposal is to avoid the applicant from going to two different authorities. If the case falls under the jurisdiction of the civil high court for instance, the applicant prior to filing the original summons for letters of representation, may first apply for the issuance of inheritance certificate from the syariah judiciary officer which is stationed at the selected court building. This allows for both process involving the inheritance certificate and letters of representation to be made under one roof as well as to speed up the time where application for both types of documents can be made at the same time.

As for ARB, the same strategy can be proposed by having a syariah judiciary officer to be placed at certain ARB branches. Alternatively, it is also suggested that, ARB could be given the authority to determine the entitled beneficiaries and their entitlement under the rules of faraid, where the syariah courts will then reaffirms the matter and issue the inheritance certificate. As a trust company which possess over ninety years of experience in dealing with estate cases, ARB is highly capable of performing such tasks through its officers who are trained in faraid calculations, which is more less similar to the expertise obtained by the land administrator (Bouteraa 2019). The key point here is that Syariah Court retains its authority as they can reaffirm the verification made by the ARB. This suggestion could reduce the volume of cases in Syariah Court in respect to inheritance certificate as well as save the time in administering the deceased's estate. Moreover, this proposal applies to both functions of the ARB, either in its role in issuing the letters of Direction and Deceleration, or assuming its role as the personal representative (Halim, Mohd Noor \& Arshad 2018).

To conclude, it is a fact that administration of Muslim's estate in its current practice requires the applicants to deal with Syariah Court and other administrative bodies. The role of the Syariah Court is undoubtedly essential in ensuring the deceased's estate shall be distributed to the entitled beneficiaries with the specified portions in line with the rules of faraid. It is also a fact that the current practice requires for improvements which could benefit the society, the administrative bodies and the government as a whole. It is also important to note that, the nature of estate administration which requires the parties to deal with individuals, groups and agencies makes it complicated and may be time consuming. Hence, the idea of reducing the complication of dealing with multiple bodies remedies a part of this problem. Through the proposed means also, the Muslims shall be able to manage the deceased's estate in a more efficient and speedier manner, as the proposal makes it easier to everyone involved. 


\section{References}

Ab Rahman, S., Md Khalid, R., Abd Razak, A. \& Jaafar, A. B. 2018. Pemerkasaan mahkamah syariah dalam pentadbiran harta pusaka masyarakat Islam menurut kerangka federalisme di Malaysia. Akademika. 88 (3): 113-125.

Ahmad Sanusi, S. W. S., Jamlus Rafdi, N., Mohamad Puad, N. A. \& Musa Sarip, M. 201). A review on bequest writing in the management of property in Malaysia. Proceeding of the 4th International Conference on Management and Muamalah 2017 (ICoMM 2017), 497-502.

Ahmad, M.Y., Jamsari, E. A., Mohd Nasir, B., Hehsen, A. \& Wan Hassan, W. Z. (2017). Flexibility of takharuj principle in solving the inheritance issues. International Journal of Civil Engineering and Technology (IJCIET). 8 (11): 867-878.

Baharudin, N. I. \& Mohamed Said, N. L. 201). Masalah dan kaedah penyelesaian pewarisan harta pusaka mualaf di Malaysia. Islamiyyat. 39 (1): 47-56.

Bouteraa, M. 2019. Barriers factors of wasiyyah (will writing): Case of BSN Bank. IBMRD's Journal of Management \& Research. 8 (1): 1-10.

Haji Mohammada, M. T. S. \& Suratman, R. 2017. Complexity of intestate estates distribution and escheat law. International Journal of Law, Government and Communication. 2 (4): 1-12.

Halim,A. H., Mohd Noor, N. A, \& Arshad, A. 2018. Administration of unclaimed estates in Malaysia: The peculiarities of unclaimed money, undistributed fund and bona vacantia. The Journal of Social Sciences Research. 6: 1075-1079.

Kamarudin, A. R., \& Ab Aziz, N. 201). Mediation in Malaysia: Is it facilitative, evaluative or transformative? West East Journal of Social Sciences 3 (1): 9-13.

Kamarudin, M. K. \& Nor Muhamad, N. H. 2018. Islamic estate planning and management: Malaysian experience. International Journal of Management Applications 1 (1): 8-16.

Nasrul, M. A. D. \& Mohd Salim, W. N. 2017. Administration of a Muslim's Estate under Section 17 of the Public Trust Corporation Act 1995 With Special Reference to Transfer of Vehicles. IIUM Law Journal. 25 (1): 121-136.

Nasrul, M. A. D. \& Mohd Salim, W. N. 2018. Administration of estates in Malaysia: determinant of factors behind the delay in the distribution of the deceased's asset. Journal of Nusantara Studies. 3 (1): 75-86.

Nasrul, M. A. D., Mohd Salim, W. N., Md Said, M. H. \& Abdul Hak, N. 2019. Family disputes in administration of estates: analysis on mediation as effective dispute resolution mechanism in Malaysia, Malaysian Journal of Consumer and Family Economics. 23 (1): 15-32.

Nasrul, M. A. D., Mohd Salim, W. N., Md Said, M. H., \& Abdul Manap, S. N. 201). Administration of estates in Malaysia: jurisdiction and misconception. UUM Journal of Legal Studies. 8: 183-196.

Omar, N. \& Muda, M. 201). Change of mazhab (school of thought): the effects on inheritance in Islamic family law. International Journal of Academic Research in Business and Social Sciences. 7 (11): 633-642.

Samori, Z., Khalid, M. M., Yaakob, M. A. Z., Fathulah Harun, H. M. \& Abdul Hamid, N. 2016. Towards managing the beneficiaries rights via writing a will. Global Journal of Management and Business Research. 16 (3): 22-29.

Shafie, F., Wan Yusoff, W. Z. \& El-Edrus, S. M. D. 2016. Factors of failure and delay in Islamic inheritance distribution in Malaysia. Jurnal Teknologi (Sciences \& Engineering). 78: 1-10.

Zulkifli, A. N., Batiha, Q. A. \& Qasim, M. M. (2018). Design and development of M-Faraid: An Islamic inheritance mobile app. Journal of Advance Research in Dynamical \& Control Systems. 10: 15691575.

https://doi.org/10.24035/ijit.19.2021.197 